\title{
Empirical Research Based on Undergraduate Employment Quality of University of Finance and Economics
}

\author{
Xuejie Bai \\ Management Department \\ Harbin Finance University \\ Harbin, China, 150030
}

\begin{abstract}
University students' employment is a social focus and undergraduate employment quality is related to the survival and development of universities and undergraduates. Under the background of developing socialist market economy many universities have set up economic and management majors. This causes graduate employment competition increasingly fierce. This article takes undergraduate employment quality of universities of Finance and Economics as research object by selecting two representative local finance undergraduate universities, analyzes the quality of the undergraduates' employment, explores strategies of improving the quality of university students' employment, we hope to provide valuable suggestions for financial graduate employment and improve career guidance and employment service in universities.
\end{abstract}

Keywords-universities of finance and economics; undergraduate; employment quality

\section{INTRODUCTION}

With the promotion of the popularization of the education and continuously expanding enrollment, the issue of undergraduate employment has become a hot topic and is concerned by the whole society. With the development of the socialist market economy, many universities have set up economic and management majors. The newly-founded universities have become one of the important parts of higher education in China as the transforming outcome from the elite to mass education. This article selects two typical universities of finance and economics in Heilongjiang Province. One was newly built in 2010 and named after University A and the other was found in 1958 as college and is called University B. By comparing the undergraduate employment quality of the two universities we try to find out the employment quality of undergraduate in different universities and how to improve it. Graduates employment quality is evaluated by society, employers, universities and undergraduates themselves. All data in the article is about the 2015 undergraduates by December 30th, 2015.

\section{BASIC SITUATION OF UNDERGRADUATES}

\section{A. Size and Structure}

There are 123,662 undergraduates in Heilongjiang Province in 2015. "Table I" The number of female university students and male university students is similar. But we can see that female university students are much more than male university students in University of Finance and Economics. Students of University A is about a third the size of University B.

TABLE I. 2015 UNDERGUADUATES GENERAL SITUATION

\begin{tabular}{|c|c|c|c|c|c|c|}
\hline \multirow{2}{*}{ University Name } & \multicolumn{2}{|c|}{ Totality } & \multicolumn{2}{|c|}{ Male } & \multicolumn{2}{|c|}{ Female } \\
\hline & Quantity & Percentage & Quantity & Percentage & Quantity & Percentage \\
\hline University A & 2041 & 0.96 & 520 & 25.48 & 1521 & 75.42 \\
\hline University B & 6190 & 2.922 & 2036 & 32.89 & 4154 & 67.11 \\
\hline Heilongjiang Province & 123662 & 100 & 58041 & 46.94 & 65621 & 53.06 \\
\hline
\end{tabular}

\section{B. Initial Employment Rate}

The first average employment rate of Heilongjiang Province is $81.21 \%$. "Table II" That of University A and University B is all above $81.21 \%$. The employment rate of Economic Management is higher than many other majors. With the economic globalization and the rapid development of global information, economics and management undergraduates are becoming more easily to find jobs now.
TABLE II. COMPARISON OF INITIAL EMPLOYMENT RATE

\begin{tabular}{|l|l|}
\hline \multicolumn{1}{|c|}{ University Name } & Initial Employment Rate \\
\hline University A & $87.95 \%$ \\
\hline University B & $91.21 \%$ \\
\hline Heilongjiang Province & $81.21 \%$ \\
\hline
\end{tabular}

\section{Choices after Graduation}

Only $2.84 \%$ of the undergraduates in University A pass the entrance examination and become postgraduates, but the percentage in University B is 8.8.There are 483 students who 
sign the employment contract in University B, but there is none in University A. Newly-built universities for undergraduates are weak in school-running idea, study atmosphere, specialty foundation, teaching management, teachers' level, and students' quality. "Table III"

TABLE III. CHOICES AFTER GRADUATION

\begin{tabular}{|l|l|l|l|l|}
\hline & \multicolumn{2}{|c|}{ University A } & \multicolumn{2}{c|}{ University B } \\
\hline & Quantity & Percentage & Quantity & Percentage \\
\hline $\begin{array}{l}\text { Agreement } \\
\text { Employment }\end{array}$ & 905 & 44.34 & 2119 & 34.23 \\
\hline $\begin{array}{l}\text { Contract } \\
\text { Employment }\end{array}$ & 0 & 0 & 483 & 7.8 \\
\hline Higher Edcation & 58 & 2.84 & 545 & 8.8 \\
\hline Going abroad & 14 & 0.69 & 139 & 2.25 \\
\hline $\begin{array}{l}\text { Unemployment } \\
\text { Contract }\end{array}$ & 246 & 12.05 & 544 & 8.79 \\
\hline Other Employments & 0 & 0 & 2006 & 32.41 \\
\hline $\begin{array}{l}\text { Special } \\
\text { Employment }\end{array}$ & 0 & 0 & 354 & 5.71 \\
\hline Total & 2041 & 100 & 6190 & 100 \\
\hline
\end{tabular}

\section{Industry Flow of Employment}

Undergraduates in University A are interested in financial industry not only because the university's history but also they may get good salary and working condition in commercial fields. University $\mathrm{B}$ is a comprehensive commercial one and its students have more scientific career choices in many fields. "Table IV"

TABLE IV. INDUSTRY FLOW OF EMPLOYMENT (IN \%)

\begin{tabular}{|l|l|l|}
\hline \multicolumn{1}{|c|}{ Industry } & \multicolumn{1}{c|}{ University A } & \multicolumn{1}{c|}{ University B } \\
\hline Financial Industry & 47.29 & 13.51 \\
\hline Wholesale and Retail Industry. & 11.93 & 10.39 \\
\hline Manufacturing Industry & 8.4 & 17.81 \\
\hline Information Software Industry & 6.85 & 13.9 \\
\hline
\end{tabular}

\section{E. Destribution Comparison of Family Location and Working Place}

There are seven geographic regions in China. From "Table V" we can see undergraduates tend to find jobs and live in urbanized regions formed along Chinese coast the Pearl River Delta, the Yangtze River Delta and the BeijingTianjin region. Undergraduates from under-developed areas, such as North East, Central China and North West, choose not to go back hometown in order to obtain more opportunities and something else. The brain drain seriously affected the economic and social development in less developed region of China. In the other words, how to attract local talent is very important thing for government.

TABLE V. DESTRIBUTION COMPARISON OF FAMILY LOCATION AND WORKING PlACE (IN \%)

\begin{tabular}{|c|c|c|c|c|c|c|c|c|}
\hline University Name & Contents & North East & North China & East China & Central China & South China & South West & North West \\
\hline \multirow{2}{*}{ University A } & Family Location & 66.93 & 3.78 & 8.03 & 3.43 & 2.2 & 4.94 & 6.91 \\
\hline & Working Place & 56.82 & 9.94 & 12.74 & 2.23 & 9.04 & 4.52 & 4.64 \\
\hline \multirow{2}{*}{ University B } & Family Location & 69.84 & 5.85 & 8.57 & 3.47 & 2.16 & 5.2 & 5.83 \\
\hline & working Place & 49.97 & 15.19 & 16.76 & 2.12 & 9.43 & 3.44 & 3.09 \\
\hline
\end{tabular}

\section{F. Nature of the Employment Unit}

These five kinds of units receive most of the undergraduates. State-owned enterprises and private enterprises hire more than $80 \%$ of all the students in Heilongjiang Province. The percentage employed by foreignfunded enterprises is 1.33 University $\mathrm{A}$, but almost five times in University B. The national average is much more higher than that of Heilongjiang Province. "Table VI"

TABLE VI. NATURE OF THE EMPLOYMENT UNIT (IN \%)

\begin{tabular}{|l|l|l|l|}
\hline $\begin{array}{c}\text { Nature of Employment } \\
\text { Unit }\end{array}$ & $\begin{array}{c}\text { University } \\
\text { A }\end{array}$ & $\begin{array}{c}\text { University } \\
\text { B }\end{array}$ & \multicolumn{1}{c|}{$\begin{array}{c}\text { National } \\
\text { Average }\end{array}$} \\
\hline State-owned Enterprises & 48.18 & 12.95 & 20.2 \\
\hline Other Enterprises & 47.40 & 74.80 & 31.5 \\
\hline Foreign-funded enterprises & 1.33 & 6.34 & 22.8 \\
\hline State Organs & 1.66 & 3.32 & 1.4 \\
\hline Other Institutions & 0.11 & 0.88 & 13.2 \\
\hline
\end{tabular}

\section{ANALYSIS OF EMPLOYMENT QUALITY}

With the serious situation now the quality of employment has became one of the most important topics concerned widely. From undergraduates, employers and their feedback we can summarize in the reasons of relating to the employment quality, then propose solutions to a targeted strategy.

\section{A. Evaluation from Undergraduate}

1) Job Satisfaction: The survey shows that $38.66 \%$ of the university students are very satisfied with their work. The percentage who are satisfied is $39.14 \%$. Only $1.15 \%$ of the students are dissatisfied with their jobs. So the data shows most of the students are satisfied with their work.

2) The level of pay: Most of the Salary of the students in University B is between RMB 2000 and 4000 a month. The percentage is $37.13 \%$ between RMB 2000 and 3000 and the ratio is $34.49 \%$ between RMB 3000 and 4000.The ratio of salary below 2000 is $7.07 \%$ and decline $5.98 \%$ in comparison with that in 2014 . The ratio of salary above RMB 4000 is $21.32 \%$ and increase $9.66 \%$ in comparison with 2014.

3) Job related to the specialty: About $37.37 \%$ of the undergranduates move into a career more closely related to their major while $32.57 \%$ closely. Almost $70 \%$ of the university students have done the relavant job.

4) Job stability: About $76.99 \%$ of the undergraduates have no plan to leave office or quit.Only $23.01 \%$ want to change jobs. The main reason is for personal development, defects in payment system and welfare system and changing jobs. Undergraduate Employment Quality is determined by not only the university students but also the employers. 


\section{B. Evaluation from Employer}

Most of the employers are satisfied with the new employees. Of couese there are a few students dissatisfied by the companies. With the increasing competition in the employment market, the employers' requirements for graduates' comprehensive ability, innovation capability, practice capability and students' ability to analyze and solve problems with professional knowledge are rising. "Table VII"

TABLE VII. QUALITY EVALUATION OF UNDERGRADUATE FROM UNITS

\begin{tabular}{|l|l|l|}
\hline \multicolumn{1}{|c|}{ Choice } & \multicolumn{1}{c|}{ University A(\%) } & \multicolumn{1}{c|}{ University B(\%) } \\
\hline Very Satisfied & 76.92 & 63.56 \\
\hline Satisfied & 19.23 & 33.38 \\
\hline Neutral & 3.85 & 2.93 \\
\hline Dissatisfied & 0 & 0.13 \\
\hline
\end{tabular}

\section{Feedback to Universties from Employers and the} Students

Universities should pay attention to the feedback from employers and students and try to improve the employment rate and quanlity and meet the demands of them. From the table we can see there are some aspects which are needed to improve such as employment guidance and service. Employers advise university to take actions to enhance students' practical ability, innovative ability and expansion of students' knowledge. "Table VIII"

TABLE VIII. UNIVERSITY EMPLOYMENT SYSTEM ASSESSMENT FROM UNDERGRADUATES (IN \%)

\begin{tabular}{|l|l|l|l|l|}
\hline \multicolumn{1}{|c|}{ Choice } & $\begin{array}{c}\text { Employment } \\
\text { Guidance }\end{array}$ & $\begin{array}{c}\text { Recruitment } \\
\text { Information }\end{array}$ & $\begin{array}{c}\text { Campus } \\
\text { Recruiting }\end{array}$ & $\begin{array}{c}\text { Employment } \\
\text { Service }\end{array}$ \\
\hline $\begin{array}{l}\text { Very } \\
\text { Satisfied }\end{array}$ & 56.70 & 60 & 58.17 & 60.91 \\
\hline Satisfied & 28.23 & 28 & 26.85 & 25.37 \\
\hline Neutral & 11.66 & 9.71 & 12.23 & 9.49 \\
\hline Dissatisfied & 2.51 & 1.49 & 1.94 & 3.2 \\
\hline $\begin{array}{l}\text { Very } \\
\text { Dissatisfied }\end{array}$ & 0.9 & 0.80 & 0.80 & 1.03 \\
\hline
\end{tabular}

\section{CONCLUSION}

After analyzing the employment quality, we put forward the following proposals in order to give some advice to improve the problems.

\section{A. Constructing Professional System of Career Guidance}

In order to solve the problems in the content system such as the incomplete of the content, the simplification of the level, the lack of consistency and pertinence constructing system of career guidance is very urgent. Fist improving the employment guidance course quality is the most important. We will integrate education resources, improve teaching methods and emphasize on cultivating students' employ ability and entrepreneurial ability. Secondly the teaching staff should have much more professional knowledge and practical experience in the major of finance and economics. Thirdly through carrying out the community, career planning competition, competition of resume, reports of alumni and other varied forms, students' career consciousness, and professional ability can be stimulated and employment competitiveness increased.

\section{B. Adjusting the Plan of Talents Training}

Every university attach great importance to the establishment and adjustment of the plan of talents training. Universities should adjust the plan of talent training and enhance the practice arrangement in education plan. When making plan of talents training university should consider requirements of development of economy and society, history themselves and actual condition, the demands of the graduates and employers. The construction of knowledge system and curriculum system should be made appropriate adjustments in the program of cultivating talents according to the demands. Increasing the hours of practice and the strengthening of practical training base building is necessary. Designing specialty cultivation platform of comprehensive capacity and constructing an open practice teaching mode for economics and economic majors have already be greatly praised by the students. By opening laboratory the college students, under the guidance of instructors, can use all the relative resources in the laboratory and strengthen their creativity and practice capability.

\section{REFERENCES}

[1] Liu Shu-yuan, Evaluation System on the Granduates Employmen Quality based on Job Happiness Index, China University Students Career Guide,348(2016)34-39.

[2] Staines,G.L.and Quinn,R.P .American workers evaluate the quality of their jobs.Monthly Labor Review, 1971(1):3.

[3] Brendan Burchell, Kirsten Sehnbruch, Agnieszka Piasna and Nurjk Agloni, The quality of employment and decent work:definitions, methodologies, and ongoing debates,Cambridge Journal of Ecnomics 2014(38); 459-477.

[4] Brisbois R. How Canda Stacks up:the Quality of Work:an International Perspective[R].Ottawa: Canandian Policy Research Network Inc., 2003(2): 31. 